\title{
O elemento árabe en galego (II)
}

\author{
Xavier Frías Conde \\ Universidade Complutense de Madrid
}

\begin{abstract}
Resumo:
A influencia do árabe sobre o galego é unha das cuestións pendentes da lingüística galega actual. Tense pensado a miúdo que o árabe non tivo influencia ningunha sobre o galego, mais isto é falso. Ducias de topónimos árabes están presentes por todo o dominio galego. Doutra banda, o galego posúe os seus proprios empréstimos árabes, diferentes dos que se achan nas linguas veciñas. Porén, debe entenderse que a presenza destes arabismos en galego é debida a un complexo proceso onde os mozárabes desempeñaron un papel fundamental.
\end{abstract}

Palabras chave:

Empréstimos árabes, toponima árabe, mozárabes, arabo-galego.

\begin{abstract}
:
The influence of Arabic upon Galician is one of the unresolved matters of the current Galician Linguistics. It has often been believed that Arabic did not have any influence upon Galician, but this is false. Dozens of Arabic place names can be found all over the Galicianspeaking area that show a clear Arabic origin. Moreover, Galician even possesses its own Arabic loanwords, different from those of the surrounding languages. Anyway it must be understood that the presence of these Arabic loanwords in Galicia were due to a complex process in which Mozarabs played an outstanding role.
\end{abstract}

Key words:

Arabic loanwords, Arabic place name, Mozarabs, Arabic-Galician.

\section{Aspectos léxicos dos arabismos galegos}

\section{Introdución}

15. Xa anteriormente tratamos das distintas posibilidades de entrada do arabismo (§7). Isto supón que, nos máis dos casos, a entrada de arabismos produciuse na lingua oral, até seren aceptados pola lingua literaria.

Mais non todos os arabismos son desta caste, senón que houbo unha vía culta de penetración, de tipo libresco, segundo xa vimos, que creou formas baixo-latinas de 
moitos destes arabismos, que despois pasaron ao románico. Tal é o caso de CAMPHORA, sobre o árabe KÂFÛR, que explica o portugués cânfora e o catalán càmfora, fronte ao galego e castelán alcanfor, que é árabe. Tamén por esta razón levan acentuación proparoxítona os termos álcali ou álxebra en todo o iberorromance, cando tal acentuación resulta de todo allea ao árabe (o artigo sempre é átono).

A grande maioría dos arabismos que entraron en iberorromance foron substantivos. Son escasos os adxectivos (e nalgún caso mesmo se substantivaron, como en jabalí [= do monte] > xabarín), máis aínda os verbos (coma xalaq > afagar [en eonaviego aínda afalagar], aínda que secundariamente, xa desde o romandalusí, ou aínda en galego, certas raíces foron verbos).

É chocante encontrar outros elementos, mais non repararemos niso agora ${ }^{1}$. Algúns casos serán analizados á fin deste traballo. En calquera caso, tamén houbo outra vía de penetración de arabismos, tales como os calcos semánticos e as influencias secundarias.

\section{Calcos semánticos}

16. O calco semántico tivo unha grande aceptación na formación de abondos termos novos. Talvez o galego non é a lingua en que a súa presencia sexa máis notoria, mais en calquera caso podemos achar algunhas mostras.

O uso dos calcos débese ao prestixio do árabe coma lingua de cultura durante moito tempo na Idade Media, como hoxe en día se fan calcos semánticos sobre o inglés. Neste caso, frecuentemente o árabe axe como adstrato, tomando como referencia, na maioría das ocasións, o árabe literario. Eis algúns exemplos:

adiantado (ga. e pt.): significaba 'xefe de tropa' e é calco de muqaddam, que ao mesmo tempo deixou almocadén (ga.), almocadém (pt.).

caer: co sentido de 'encontrarse' é outro calco do uso secundario do árabe wáqa3 (= caer). Non obstante, aínda que cun sentido máis restrito, encóntrase tamén en francés.

de bruces (ga.); de bruços (pt.): é un curioso cruce basco-arábigo, onde se combinan o eusquera buruz (= de cabeza) co árabe bûs (reverencia, que deu xacando o español buz). Do cruzamento e fusión coa forma basca saíu a expresión anterior, cun derivado debruzar [debruçar].

fidalgo: baséase na construción árabe con ibn (= fillo) máis un substantivo. Así, dicíase ibn allayl (= fillo da noite) para referirse aos ladróns o ibn yáwmih (=

\footnotetext{
1 Citaremos apenas a preposición até, derivada do árabe hattà.
} 
fillo do seu día) (Coromines1987: 320). Canto á forma románica, non é a única que se coñecía na Idade Media, posto que, daquela, á imitación do modelo árabe, dicíase en castelán con $f i$ o hi (ou a forma completa) fi de puta, fi de perra (este tamén en árabe ibn kálba), hijo de la caridad, hijo del naipe, etc. O noso fidalgo deriva, por tanto de fillo d'algo, que significaba 'home de diñeiro'. Neto (1992: 344) engade que o calco está feito sobre ibn alxums, onde alxums (= a quinta parte) se refire a que un quinto das terras conquistadas eran gardadas para fins benéficos. Téñase en conta que en galego son comúns expresións como fillo da cadela, calcada da fórmula árabe enriba citada.

pía madre, dura madre: as dúas membranas chámanse tal cal en árabe: alúmm alhanûn (= nai misericordiosa) e alumm aljâfiyya (= nai dura). En portugués úsanse as formas latinizadas pia mater e dura mater.

res: segundo Corrientes e Coromines, o termo non pode provir etimoloxicamente do árabe rás [=cabeza] (<cl. râ’s), mais do latín RES. Sen pormos en dúbida a opinión deles a respecto do étimo, si cremos, non obstante, que se trata dunha influencia secundaria, pois que sobre o latín RES (= propriedade) influíu a avandita voz árabe, que seguramente tiña unha pronuncia /'re:s/ con imala de segundo grao. En galego e castelán a voz ten xénero feminino, mais en eonaviego (e tamén en asturiano) teno masculino, o cal viría apoiar esta nosa teoría.

\section{Influencias secundarias}

17. Entendemos por arabismos secundarios aqueles en que a orixe dun fenómeno non é árabe (xeralmente será latina), mais é previsíbel ou seguro que o árabe favoreceu o seu desenvolvemento en galego (e iberorrománico), xa sexa no campo léxico ou morfosintáctico. Segundo esta teoría, unha tendencia románica vese reforzada por un fenómeno igual ou equivalente en árabe e que favorece que se reforce ou se desenvolva máis amplamente nas linguas iberorrománicas do que noutras familias románicas.

18. A adición de $a$ - a abondos verbos con sentido causativo ten o seu equivalente na cuarta forma verbal árabe: afa3al, é dicir, unha estrutura $\{\mathrm{aKKvKa}\}$, fronte á primeira $\{\mathrm{KvKvKa}\}$. Salomonski (1944) chegou a afirmar que era unha influencia árabe, baseándose no funcionamento comparado que ten o prefixo árabe a respecto do español (e neste caso podemos amplialo ao galego-portugués igualmente):

$1^{\text {a }}$ forma

ћázina (= estar triste)

káruma (= ser honrado)

mât $(=$ morrer $)$

dáxala (= entrar) $4^{\mathrm{a}}$ forma

áћzana (= entristecer)

ákrama (= honrar)

amâta (= matar)

ádxala (= introducir) 
Salomonski fixouse en matar e amatar do castelán antigo para chegar a tal conclusión, apoiándose ademais noutros verbos como aminorar, acalorar, abrandar, mais tal $a$ - ten a súa orixe no AD- latino. En todo o caso, a súa maior frecuencia nas linguas iberorrománicas pode perfectamente estar favorecida polo uso causativo árabe de $\{a-\}$. De calquera modo, non nos parece descartábel que o propio verbo matar, proprio das linguas iberorrománicas, proceda do verbo árabe mât ou o seu derivado amât (de feito en asturiano úsase aínda amatar), que probabelmente provén de mât, a voz utilizada no xadrez. Coromines, porén, propónlle un étimo latino *MATTARE, derivado de MATTUS. Para nós, mât combínase con prefixos e sufixos románicos en romandalusí e presenta (A)MAT-ARE, con perfecta explicación semántica.

19. Os plurais duais típicos das linguas iberorrománicas do tipo os pais, os reis, os fillos, os irmáns son posíbeis nas demais linguas románicas, ao menos nas occidentais (e tamén comúns en sardo), mais son especialmente frecuentes nas ibéricas. En latín xa se coñecía este uso en PATRES (por PARENTES), FILII, FRATRES. O árabe emprega o mesmo recurso, onde o masculino é unha forma non marcada que se refire a ambos os xéneros en plural, de maneira que a súa influencia ben puido reforzar este uso xa latente desde o latín.

20. Os días da semana galego-portugueses, mellor conservados en portugués do que en galego, poden terse afianzado na súa forma actual por posuíren unha estrutura paralela á dos días da semana árabes, que se saen, como é de esperar, do esquema típico das linguas europeas, especialmente as románicas, que seguen o vello padrón latino das deidades pagás². Obsérvese este curioso paralelismo, onde, ademais, o primeiro día da semana é o domingo.

$\begin{array}{ll}\text { yawm alhad } & \text { domingo } \\ \text { yawm al'ipnayn } & \text { segunda-feira } \\ \text { yawm appalâpâ' } & \text { terza-feira } \\ \text { yawm al'arba3â' } & \text { cuarta-feira } \\ \text { yawm alxamîs } & \text { quinta-feira } \\ \text { yawm aljúma3 } & \text { sexta-feira } \\ \text { yawm assábt } & \text { sábado }\end{array}$

21. Os verbos amencer / anoitecer empréganse na primeira e segunda persoas en todo o iberorrománico para indicaren que o falante ou o ouvinte apareceron na primeira ou na derradeira hora do día en tal lugar ou circunstancia. Esta utilización é

\footnotetext{
2 A denominación cristiá foi imposta polo papa Silvestre no 316 .

3 O significado dos nomes arábicos son: o día primeiro, o día segundo, o día terceiro, o día cuarto, o día quinto, o día da asemblea (islámica, día santo musulmán), o día do sábado.
} 
habitual en árabe, mais non é descoñecida en francés e occitano, aínda que ten un uso máis desenvolvido en romeno (e aquí tampouco é descartábel unha remota influencia árabe por medio do turco).

22. As respostas eco do galego-portugués son coñecidas tamén en árabe, utilizándose para contestar afirmativamente tamén o mesmo verbo con que se pregunta:

En árabe:

- Hal turídu 'an tâ'ti?

- Urídu

En galego:

- Queres vir?

- Quero

23. Nas linguas iberorrománicas é normal utilizar o xiro que vén (ga.), que vem (pt.), que viene (es.), no canto dun adxectivo para se referir a períodos de tempo do futuro, do tipo o ano / mes que vén (convivindo con vindeiro, igual que o sardo bennidore). Tal estrutura utilízase igualmente en árabe:

al-yawm allâđi jâ'iy (literalmente: 'o día que está vindo')

En árabe emprégase tamén para se referir ao pasado: alusbû3 allađi fât (= a semana que pasou).

24. A orde de palabras en iberorromance é bastante máis libre que noutras linguas románicas. Admite Lapesa (1984: 151) que o influxo árabe é posíbel (en castelán), endebén, recoñece que faltan estudios ao respecto. Non desbota que a frecuente inversión de suxeito e verbo sexa unha influencia arábica nas nosas linguas, dado que en árabe antigo -porén non nos dialectos modernos (Frías Conde 1998)- a orde normal é $\mathrm{V}+\mathrm{S}$. Non hai unha razón clara en galego -e en xeral en iberorrománico- para que abunden as oracións en que se dá a orde $\mathrm{V}+\mathrm{S}$ (nas carxas hai algunhas mostras diso), polo que non tería nada de estraño que por medio do romandalusí esta tendencia callase en galego. Iso explicaría (ao menos parcialmente) por que son máis comúns as construcións do tipo:

Galego: Góstame o pan

Árabe: Tu3ajibuniy alxubz.

Non cremos que o fenómeno teña orixe árabe, mais insistimos no aspecto de influencia secundaria. Obsérvese que tal construción é o normal en italiano, $M i$ piace il pane, mentres que o portugués desenvolveu unha construcción con suxeito actor, Gosto do pão, que resulta xa arcaica en castelán: Gusto del pan fronte a me gusta el pan, que, en troque, é a estrutura favorita do francés (J'aime le pain). 
25. A grande tendencia á impersonalidade do verbo (trazo non só iberorrománico, mais tamén proprio do occitano, do italiano e do sardo) vese favorecido polo árabe, especialmente no uso da 3PP para esta finalidade:

Galego: Venden melóns no mercado

Árabe: Yabî3ûna bațtîx fi-ssûq

Sardo: Vendent melones in su mercadu

26. Poderiamos pensar que as construcións tan frecuentes de oracións sen cópula teñen tamén un apoio no árabe (este é outro fenómeno pan-iberorrománico). Oracións como

1. Os nenos, na cama (ár. alwilâd fi-ssarîr)

2. Eu, de momento ben (ár. ana jayid al'ân)

3. O partido, este xoves (ár. almubârah fi hâđa yawm alxamîs)

son habituais, e úsanse nas mesmas condicións que en árabe, é dicir: a) para indicar estado e posición, e b), normalmente en presente (a cópula vai non marcada). É ben certo que en latín xa existían construcións iguais, mais non están moi espalladas en románico, agás na Península Ibérica, polo que podemos acudir ao árabe para explicar a súa frecuencia.

27. Canto á orixe do infinitivo flexionado galego-portugués, sobre o que tanto se ten especulado, ten, sen dúbida, unha xénese románica, tal como se entende polas desinencias e porque aparece en áreas dispares da Romania, como Galiza-Portugal e Sardeña. Mais podería existir unha influencia secundaria arábica en galego-portugués que favoreceu o seu desenvolvemento neste diasistema e non no resto do iberorrománico. Non posuímos datos que nos aclaren se o infinitivo flexionado ou algo semellante xa existía en romandalusí, mais, debido á forte grao de penetración árabe, puido darse un sistema mixto de infinitivo (que si coñecía o romandalusí á diferencia do árabe, que non o ten) con desinencias, é dicir, que o uso constante de desinencias do árabe pasase ao romandalusí.

Obsérvese como nas seguintes oracións árabes se utiliza unha forma flexionada, mentres que en español se emprega ora un infinitivo, ora unha forma de conxuntivo, en dous casos en que o galego-portugués (e sardo) non hesita en utilizar o infinitivo flexionado:

(a): Adxacente do N no SN:

árabe: Al'ân sâ3at tađhab li-lbayt (lit.: 'agora (é) hora de vas á casa')

español: Es hora de ir a casa / de que te vayas a casa

galego-portugués: É hora de ires para a casa

sardo: Est ora d'andares a domo (tua) 
(b) SP de finalidade:

árabe: Naštagilu litadrus (lit.: 'traballamos para estudias')

español: Trabajamos para que estudies / para tú estudiar ${ }^{4}$

galego-portugués: Traballamos \{trabalhamos\} para ti \{tu\} estud(i)ares.

sardo: Traballiamus pro istudiares (tue)

Sicilia foi zona de influencia árabe, non tan intensa coma na Península Ibérica, mais si o suficiente como para que esta lingua tamén favorecese o desenvolvemento. A respecto de Sardeña, dificilmente poderiamos acudir á influencia secundaria do árabe.

\section{O arabismo en galego e en portugués}

28. Anteriormente comentamos que o galego e o portugués presentan unha serie de semellanzas e de diferencias. Malia estarmos no mesmo diasistema, ambos os codialectos tiveron unha época -a da unidade lingüística galegoportuguesa- en que os arabismos son basicamente coincidentes, mais posteriormente existen importantes diferencias entre os falares de alén e aquén Miño.

Un dos aspectos que resulta máis interesante é a distribución dos arabismos por zonas. En portugués, Cintra (1983: 173-178) estudiou a distribución do arabismo en Portugal ${ }^{5}$, establecendo unha longa lista de dobretes arabo-románicos. Tal lista, aínda que máis curta, é tamén propria do galego, embora non sempre se trata de sinónimos, mais por veces ambos os termos, o románico e o arábico, teñen arestora significados diferentes. Neto (1992: 380) tamén se ocupou do asunto, chegando á conclusión de que a influencia do romandalusí sobre o portugués foi maior que sobre o castelán (e, loxicamente, sobre o galego).

Reproducimos unha parte da lista de Cintra, incluíndo as parellas que existen tamén en galego e engadindo algúns termos que non foron tomados en consideración polo mestre portugués, así como outros termos que faltan nunha parte do repertorio, xeralmente en galego:

4 Esta construción atópase en certas zonas do español americano, como Colombia. No español europeo é estraña, mais é normal en asturiano.

5 Cando os termos sinalados si son sinónimos, Cintra demostra como nos máis dos casos o termo románico aparece no norte, mentres o arábico é común no sul. 


\begin{tabular}{|c|c|c|c|}
\hline \multicolumn{2}{|c|}{ Románico } & \multicolumn{2}{|c|}{ Árabe } \\
\hline Portugués & Galego & Portugués & Galego \\
\hline $\begin{array}{l}\text { cabaz } \\
\text { cesto } \\
\text { represa, poça } \\
\text { castelo } \\
\text { sobrenome } \\
\text { vazio } \\
\text { cisterna } \\
\text { lagoa } \\
\text { apogeu } \\
\text { vigra, esculca } \\
\text { moinho-de-água } \\
\text { fonte } \\
\text { lande } \\
\text { feito } \\
\text { sujeito } \\
\text { lenço } \\
\text { porco-montês } \\
\text { queira Deus } \\
\text { espiga } \\
\text { solto } \\
\text { segada } \\
\text { quarto } \\
\text { bigorna } \\
\text { decrua } \\
\text { livro velho } \\
\text { dedal } \\
\text { cavaleiro } \\
\text { povoação } \\
\text { presidente da câmara } \\
\text { poupar } \\
\end{array}$ & 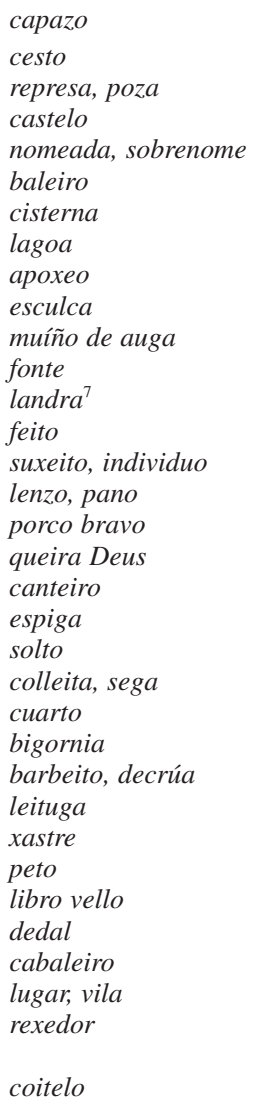 & $\begin{array}{l}\text { açafate } \\
\text { alcofa } \\
\text { albufeira } \\
\text { alcaçova } \\
\text { alcunha } \\
\text { alfeire } \\
\text { algibe } \\
\text { alverca } \\
\text { auge } \\
\text { atalaia } \\
\text { azenha } \\
\text { chafariz } \\
\text { bolota } \\
\text { façanha } \\
\text { fulano } \\
\text { mandil } \\
\text { javali } \\
\text { oxalá } \\
\text { alvanel } \\
\text { maçaroca } \\
\text { ceive } \\
\text { safra (Brasil), ceifa } \\
\text { alcova } \\
\text { safra } \\
\text { alqueire } \\
\text { alface } \\
\text { alfaiate } \\
\text { algibeira } \\
\text { alfarrábio } \\
\text { alferga } \\
\text { alferes } \\
\text { aldeia } \\
\end{array}$ & $\begin{array}{l}\text { azafate } \\
\text { albufeira } \\
\text { alcuña, alcuño } \\
\text { baldeiro }{ }^{6} \\
\text { alxibe } \\
\text { alberca } \\
\text { auxe } \\
\text { atalaia } \\
\text { acea } \\
\text { chafariz } \\
\text { fazaña } \\
\text { fulano } \\
\text { mandil } \\
\text { xabarín } \\
\text { oxalá } \\
\text { albanel } \\
\text { mazaroca } \\
\text { ceibe } \\
\text { ceifa , zafra } \\
\text { alcoba } \\
\text { zafra } \\
\text { alqueive } \\
\text { (alfaça) [antigo] } \\
\text { (alfaiate) [antigo] }\end{array}$ \\
\hline
\end{tabular}

Como se pode apreciar, existen casos de arabismos galegos descoñecidos en portugués.

6 Non debe ser propriamente un arabismo, mais sobre baleiro houbo un cruzamento con balde, que si é árabe, e xurdiu baldeiro.

7 Eonaviego lande.

8 Neto (1992: 380) non consigna este termo no portugués do Norte, mais só no do Sul. Porén, existe en galego, onde está perfectamente documentado. Alén diso, é curiosa a mudanza de significado que ten o termo en castelán aceifa, que significa 'campaña militar do verán'. En ambos os casos, o galego-portugués e o castelán, o seu étimo é AŞŞÂ’IFA (véxase máis abaixo). 


\section{Estudios léxicos e toponímicos}

29. Nesta última parte estudiaremos algúns elementos léxicos individualizadamente. Incluímos voces de todo o dominio galego, mesmo do galego de Asturias ou eonaviego. Tamén faremos referencia a topónimos. Usaremos constantemente as abreviaturas and. para andalusí e cl. para clásico (referido sempre ao árabe).

aba: 'antiga medida'. Provén do andalusí $\hbar a ́ b b a$ (= gran, anaco, parte miúda de algo). Deste mesmo étimo deriva tamén $f a b a$, que resulta homófono co legume, mais trátase dunha derivación máis antiga pola conservación de /f-/ proveniente de $/ \hbar /$. Esta faba significa 'vulto baixo da pel' e tamén ten referente no castelán haba (coa mesma homofonía) e no portugués fava (ídem).

Abuzalema: topónimo de Ourense derivado do antropónimo Abû Salâma.

aceal: 'tenaces do albeite', do and. azziyár < cl. ziyâr. En castelán acial ou aciar, en port. aziar.

acensalí: 'mofo que sae nas pedras, lique'. Pode vir do and. assalsalí < cl. salsalî (=en cadea).

achaque: do and. ašš́kiya (= queixa) $<\{$ škw $\}$. É curioso o tratamento de $/ \int /$ como $/ \mathrm{t}] /$.

aderado: atendendo ao seu significado de 'ponderado, xusto', pode vir do and. 3ádil < cl. 3ádil (= xusto), cun incremento románico.

adramán: 'home corpulento e mal composto', deriva do antropónimo árabe $3 a b d$ arraћmân, tradicionalmente transcrito como Abderramán.

agarimo: do and. g'arím < cl. g'arîm (= debedor).

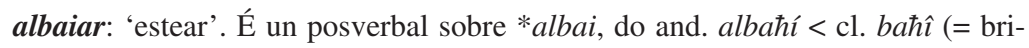
llante); en castelán existe albahío, do mesmo étimo.

alcatifa: do and. alqatífa < cl. qatîfah (= cobertor). En castelán é raro catefa, mais en catalán o único termo común é catifa, como en galego-portugués, sen artigo asimilado, que é máis frecuente nesta lingua.

alcouce: 'ángulo ou recanto abeirado que forman as casas'. En portugués, porén, é 'lupanar' e presenta tamén a forma alcoice. As dúas voces poden ter a mesma orixe, aínda que con significados distintos. Para a voz portuguesa proponse o étimo andalusí alqáws (= arco) e tamén assúq (= o mercado), cunha metátese debida aos mouriscos bilingües.

alcucifar: 'fregar o chan cun pano'. A voz galega é irmá da castelá aljofifar e da portuguesa alcufifa. Vén do aljaffafa (cunha variante con imala aljufífa). 
Aldurfe: topónimo de Riotorto, Lugo. Ten a súa orixe no andalusí adduff $<$ cl. duff (= tamboriño). Na fala áchase o arabismo adufe, existente tamén en portugués, castelán e catalán (neste último alduf con restitución ultracorrecta do /l/ do artigo que non existe en árabe, como tamén ocorre no topónimo). O topónimo galego levaría, ademais, un /r/ parasito, algo moi frecuente nos arabismos.

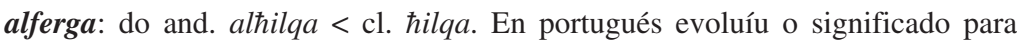
'medida de xunco para grans'. En eonaviego, alén do dedal, é un vaso pequeno para tomar augardente.

alfolín: 'almacén de sal', do and. alhúry < cl. hurî (= celeiro). En eonaviego ten ademais o significado de 'aloucado', por algunha estraña evolución semántica.

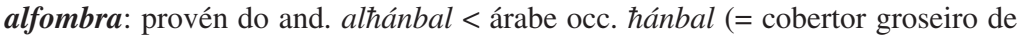
la), que deu orixinariamente a forma aínda portuguesa alfâmbara, orixe da actual alfombra. A voz é sinónima en galego e portugués de alcatifa (véxase antes).

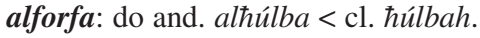

algarabear: 'berrar', derivado de algarbía, que vén do andalusí al3arabíya < cl. al3arabiyya (= a lingua árabe).

algarife: 'certa embarcación e rede do Miño'. Esta voz é algerife en portugués. É curioso o distinto tratamento de / $\mathrm{d}_{3} /$ en galego e portugués, onde a forma galega é máis antiga pola vocal /a/ e pola pronuncia /g/, mentres que a portuguesa se mostra máis evoluída. En troque, en castelán aparece como aljarfa e aljerife. Vén do ár. aljârifah (= instrumento de arrastre).

alicates: do and. hađiqát (= hábiles, sutís)

alicereces: and. al'isás < cl. isâs (= fundamentos). Ten un /// parasito que é abondo frecuente.

almorábide: vid. Rábade.

alxaba: do and. alja3ba < cl. ja3abah. En eonaviego alxaba significa o mesmo que o portugués algibeira.

alxibe: esta voz, como outras cantas, teñen a súa orixe nos distintos derivados de $\{\mathrm{jbb}\}$. Así, alxibe vén do and. aljíb $<\mathrm{cl}$. jîb.

ámago, coa variante sámago e magolo, e en port. âmago. Vén do and. xámaj< cl. $x a m j$ (= balor).

andoriña: a etimoloxía árabe que propón Corrientes para este termo é inviábel. Deriva do latín HIRUNDINE, como se mantivo sempre, con influencias secun- 
darias, especialmente do verbo andar. A forma eonaviega andolía e a asturiana andarina apoian a romanidade do termo.

atalaia: é voz común e tamén topónimo moi espallado por Galiza e a Asturias de fala galega; non ofrece ningún problema etimolóxico: vén do and. ațțaláya3 $<$ cl. țalâyi3 (pl. de țalî3ah, 'avanzada').

ataúde: esta voz galego-portuguesa deriva do and. attabút < cl. tâbût. En eonaviego existe $a t a(b) u l$, como en aragonés, cun tratamento de /-t/ final que non é frecuente.

axacar: Corriente deriva a voz desaxacado do árabe $\breve{s} a k l$ (= forma), mais podería provir da raíz $\{$ šky\}, que si deixa abondos derivados en iberorrománico.

axóuxure: do and. aljúljal < cl. juljul. Ten a variante alxóuxere e existe tamén en portugués como aljorge, aljorce.

azabal: 'cagallón da lebre, coello ou perdiz'; segundo Corrientes, esta é unha voz única en iberorrománico que el deriva do and. zabl $<$ cl. zibl (= excremento).

azafate: 'bandexa', do and. safát < cl. safaț.

azamelar: 'secar os cereais no verán'. Pode vir do ár. samal (= resistir, pola lentitude en secaren), aínda que tamén podería provir de zamân (= 'tempo', convertido en verbo en románico co sentido de 'apurar o tempo').

bandougo: é voz eonaviega. Sobre bandullo debeu sufrir un cruzamento co derivado do termo árabe búnduqa (= abelá) > albóndega .

baraza: do ár. marasah (= corda).

Barxa: topónimo espallado por toda a Galiza e que mesmo se encontra no Baixo Bierzo e As Portelas (Zamora). Debe derivar dunha forma andalusí *barj(a) $<$ cl. $\operatorname{burj}(=$ torre), probabelmente por ter unha función de vixilancia. É un topónimo de orixe militar como atalaia e mántaras.

batán: xeralmente esta voz é dada como de orixe románica, derivándoa do verbo bater. Porén, en árabe andalusí documéntase bațțan como verbo, o cal permítenos derivar a voz románica do árabe.

botefa: 'caste de melón para o caldo’, do and. baț,íxa < cl. biț,tixah (= melón).

cáceres: termo que é exclusivo do galego. Refírese ás oscas no xugo e na moa do muíño. Provén do ár. kasr (= corte).

caraba: 'xuntanza', do and. qarába < cl. qarâbah (= os parentes).

caraxe: do ár. $\hbar a r a ̂ j j$ (= noxo). 
cazo: a forma masculina está formada sobre unha feminina caza perdida nos romances, mais que deriva do árabe andalusí qás $3 a<\mathrm{cl}$. qis $3 a$ (= cunca).

Ceide: topónimo que se encontra en varios puntos da Galiza. Provén de Zayd (antropónimo). Presenta tamén a variante máis arcaica Zaide en Guntín, Lugo.

ceibe: do and. sâyib < cl. sâ'ib (= solto).

ceifa: do and. şáyfa < cl. şấifa (= tempo de recolleita, de ceifa, no verán)

cibico: é voz do galego oriental que ten a mesma orixe que cibica do castelán e sibica do portugués consignadas por Corrientes (1999). Proveñen de sabíka (= banzo da cadea) < cl. sabîkah (= lingote fundido, barra). Existe un cibique en castelán de Estremadura que significa 'anaco grande de pan'.

cide: hai varios topónimos que levan esta base Sîd (=señor) < cl. Sayyid. Eis os exemplos, algúns deles híbridos arabo-románicos: Vilacide (Xermade, Lugo), Vilacide de Arriba e de Abaixo (Oroso, A Coruña), Abucide (Toques, A Coruña $<a b u$ síd), Cedelo (Valga, Pontevedra).

cofaina: tense por castelanismo en galego, explicando que o /x/ castelán foi adaptado como /k/ en galego, mais non é así. Trátase dun arabismo antiquísimo do galego, con /g/ que inicialmente se deu en pronunciar $/ \mathrm{k} /$. En Corrientes (1999, s.q.) pódense ver outras variantes iberorrománicas con /k/ ou /g/.

eis: a primeira parte deste deíctico galego-portugués é árabe, como ocorre co castelán he aquí (moderno, mais antigo só he) e o catalán heus. O deíctico andalusí há $(<\mathrm{cl}$. hâ) deixou, xa que logo, pegada en todos os romances ibéricos.

faragán: está documentado o dito xará kán en andalusí, que quere dicir 'merda foi', e tal parece a orixe do vocábulo galego.

farrapo: podería vir do and. $x a r(r) a ́ b<$ cl. $x a r(r) a b$ (= estragar). A hesitación verbo de $/ \mathrm{f} / \mathrm{e} / \mathrm{r} /$ explica o galego farrapo fronte ao castelán harapo. Corrientes explica o/p/ como unha influencia abondo lóxica de trapo. $\mathrm{O}$ que resulta ben interesante é comprobar a familia de derivados galegos sobre a mesma raíz, onde Corrientes cita farramalla e poderiamos incluír furrumalla, voz tamén astur-leonesa, e seguramente tamén a eonaviega zarapalla, que provén de farapalla, e que se deriva doadamente de farrapo.

farruco: do and. farrúj < cl. fârrûj (= polo). A pronuncia de /dz/ coma /k/ dá conta da antiguidade do empréstimo.

foula: Corrientes recolle varios significados desta voz galega: 'farrapo de neve' e 'escuma', mais non 'onda', que é a máis espallada e a que comparte co astur-leonés fola e o castelán ola. Provén de ћáwla (= turbón). 
furrica: do and. *alxurr (máis seguramente sufixación románica) < cl. xurr' (= excremento).

galbana: a terminación románica vai cunha raíz árabe galb. A forma eonaviega é galbá, con tratamento de -ana > -á.

Gándara: Corrientes trata de xustificar este termo desde o árabe, mais faise difícil pola raíz ganda que se ten tradicionalmente coma prerromana. Doutra banda, o incrementativo - $r a$ é frecuente en moitos outros termos prerromanos.

garfo: do and. gárfa < cl. garfah (= puñado). Derivado intrarrománico é garfela e provén do mesmo étimo garra (co seu posverbal agarrar -cf. o catalán agafar, que ten igualmente este étimo).

gato: vén do and. qațt, < cl. qiț,t. O proprio latín CATTUS é voz semítica, concretamente aramea segundo Corrientes (1999, s.q.), mais a románica só pode estar tomada do árabe, cun tratamento /q/ > /g/, pois que outramente teriamos en galego * cato.

lacazán: provén dun anterior *calazán, que á vez provén do and. kaslán < cl. kaslân (= folgazán). Segundo Corrientes (1999), o sufixo \{-án\} adxectivador provén do árabe. Probabelmente é moi esaxerado afirmar talmente e ten orixe latina (<-ANE), mais non hai dúbida de que a súa presencia en romance e tamén en árabe, cun valor semellante, favoreceu a súa difusión, seguramente desde o romandalusí. Por tanto, por influxo árabe si aparecería, na nosa opinión, en folgazán (como xa sostén Corrientes), batán.

louca: a voz feminina é a orixinaria, mentres que o masculino louco é voz analóxica. Provén do and. lawqa $<$ lawqấ.

Maimón ou Meimón: topónimo de Irixoa, A Coruña. Existe tamén o topónimo Pozo Maimón no río Miño perto de Ourense. Provén do antropónimo Maymûn.

maluco: voz eonaviega con que se chama ao furuncho. Debe estar relacionada etimoloxicamente coa catalana (a)maluc (= óso da cadeira), do árabe $3 \mathrm{azm}$ alћuqq Trataríase dunha identificación da prominencia da cadeira por mor do óso con outras prominencias máis pequenas, aínda que perfectamente visíbeis, especialmente no rostro.

Mántaras: topónimo de Irixoa, A Coruña, e de Tapia de Casarego, Eonavia. Provén de *mántara < cl manțarah. (= atalaia).

maquía: do and. makíla < cl. makîlah (= cousa medida).

marabedí: vid. Rábade. 
Marbán: topónimo de Castrelo (Ourense), derivado do antropónimo árabe Marwân.

Názara: topónimo de Cenlle, Ourense, derivado do antropónimo Nâşir.

Outes: topónimo da Coruña. Antigamente tiña a forma Doutes, o cal permite identificala cun topónimo irmán, Doude, en Viseu. A súa orixe é o antropónimo Dâwûd (equivalente ao hebreo David).

papoula: do andalusí happapáwr.

Rábade: topónimo de Lugo. Este nome de lugar vén dunha raíz $\{r b t ̧\}$ cun significado de 'ligar, ligazón; amarre' (obsérvese que a capital actual de Marrocos é Rabat, da mesma orixe). A forma de que provén é rábaț (= posto de fronteira), e un derivado desta voz é almorábide (= acantoado na fronteira) e tamén a moeda marabedí. O tratamento de /ț/ como /d/ en románico non é frecuente, mais dáse nalgunhas ocasións, especialmente nos empréstimos máis antigos.

rexelo: formado sobre o and. raşá (= cría de gando) > cl. raşấ cun sufixo románico. Existe a variante rixelo.

risco: do and. rízq, cl. > rizq (= fado divino).

Sada: topónimo de Sada (A Coruña), do antropónimo Sa3d.

San Mamede: topónimo moi espallado en toda a Galiza. Provén de Maћammad $<$ Muћammad (o nome do profeta), seguramente proprio de mozárabes.

tabán: é voz románica, mais penetrada polo árabe, que á súa vez a tomou do romandalusí (o castelán tomouna dereitamente do latín: TABANU > tábano). A forma andalusí e romandalusí é ațtabán, que explica tamén perfectamente o portugués atabão. En eonaviego é tabanón, cun sufixo aumentativo, mais da mesma orixe.

taleiga: a forma talega non é castelanismo, mais explícase sinxelamente por analoxía co sufixo habitual - ego/a. Existe variante con /1/ caedizo, teiga, que dá lugar ao verbo ateigar. Igualmente, en portugués existe a mesma hestiación: taleiga, teiga . Vén do and. ta3líqa < cl. ta3lîqah (= acción de pendurar).

tixela ou tixola: palabra formada coa axuda do sufixos románicos unidos á raíz andalusí tajín ou tayjín (= ola de barro).

Viavélez: El Franco, Asturias. Popularmente é chamada El Porto, mais non pensamos que se trate dun topónimo de recente acuñación, dado a súa estraña forma. Está relacionado con outros varios vélez da Península. Proviría de vía, deformación de $b i<$ and. bíb (= porta) con imala $<$ cl. bâb e and. bálad (= país, poboación) > cl. balad. A sílaba /bi:/ é idéntica á que aparece na Puerta 
de la Visagra en Toledo, co mesmo significado. O nome completo significaría algo así como 'Porta de entrada ao país', entendendo como tal a entrada desde o mar para a Península.

zuna: do and. súnna < cl. sunnah (= tradición). Obsérvese como existe o cultismo sunnita para facer referencia a un dos grupos maioritarios do islamismo.

\section{Referencias bibliográficas (I e II)}

Alonso, A. (1947): “Árabe -st- esp -ç-, español -st- árabe ch-" [reimpreso en Estudios Lingüísticos, Gredos : Madrid, 1967], Publications of the Modern Association of America, 62: 325-338

Alonso, A. (1957): "Las correspondencias árabigo-españolas en los sistemas de sibilantes", Revista de Filología Hispánica, 8: 12-76.

Cintra, L.F. (1983): Estudos de Dialectologia Portuguesa, (Lisboa: Sá da Costa).

Corominas, J (1987): Breve diccionario etimológico de la lengua castellana (Madrid: Gredos).

Corral Díaz, E. (2000): “As cantigas de amigo", en Brea, M. (coord.): Galicia: Literatura. Tomo I. A Literatura Medieval: 118-121 (A Coruña: Hércules de Edicións).

Corrientes, F. (1966): "Hacia una revisión de los arabismos y otras voces con étimos del romance andalusí o lenguas medio-orientales en el Diccionario de la Real Academia Española”, Boletín de la Real Academia Española, 86: 55-18.

Corrientes, F. (1977): A Grammatical Sketch of the Spanish Arabic Dialect Bundle (Madrid: Instituto Hispano Árabe de Cultura).

Corrientes, F. (1999): Diccionario de arabismos y voces afines en iberorromance (Madrid: Gredos).

Cunha Serra, P. (1967): Contribuição Topo-antroponímica para o Estudo do Povoamento do Noroeste Peninsular (Lisboa: Publicações do Centro de Estudos Filológicos).

Eguilaz, L. (1886) [reimpresión, Madrid, Atlas, 1974]: Glosario etimológico de las palabras españolas (castellanas, catalanas, gallegas, mallorquinas, portuguesas, valencianas y bascongadas) de origen oriental (árabe, hebreo, malayo, persa y turco), (Granada: La Libertad).

Frías Conde, F. X. (2000): “Algunos paralelismos evolutivos entre el árabe vulgar y las lenguas románicas”, Iапиa, 1. http://www.iaga.com/ianua/araborromanico.htm

Galmés Fuentes, A. (1983): Dialectología mozárabe (Madrid: Gredos). 
Iordanu, I. / Manoliu M. (1989): Manual de Lingüística Románica. Vol II. (Gredos: Madrid).

Lanciani, G. / Tavani, G. (1993): Dicionário da Literatura Medieval Galega e Portuguesa (Lisboa: Caminho).

Lapesa, R. (1984): Historia de la Lengua Española (Madrid: Gredos).

Machado, J.P. (1991): Vocabulário Português de Origem Árabe (Lisboa: Notícias).

Maíllo Salgado, F. (1983) Los arabismos del castellano en la Baja Edad Media (Consideraciones históricas y filológicas) (Salamanca: Universidad de Salamanca).

Menéndez Pidal, R. (1950): Manual de Gramática Histórica Española (Madrid: Espasa-Calpe).

Neto, S. da Silva (1992): História da Língua Portuguesa (Presença: Rio de Janeiro).

Noll, V. (1996): "Der arabische Artikel al und das Iberoromanische", Romania arabica. Festschrift für Reinholdt Kontzi zum 70 Geburstag, 299-313 (Tübingen: Narr).

Sabbagh, M. (1932): Diccionario arábigo-español (México).

Salomonski, E. (1944): Funciones formativas del prefijo a-, estudiadas en el castellano antiguo (Zúrich) [reseñada por Eva Seifert, Vox Romanica, 10: 306-309).

Solá-Solé, J. M. (1968): "El artículo al- en los arabismos del iberorrománico”, Revue de Philologie, 21, 275-278.

Vasconcelos, C. Michaëlis de (1946): Lições de Filologia Portuguesa (Lisboa). 